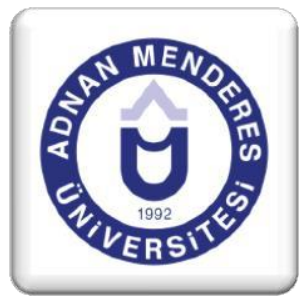

\title{
Mobil Reklam Faaliyetlerinin Tüketici Algısı Üzerine Etkileri: Üniversite Öğrencilerine Yönelik Bir Araştırma
}

\author{
Mustafa DOĞANER ${ }^{1}$, Yasemin KUYUCULAR ${ }^{2}$
}

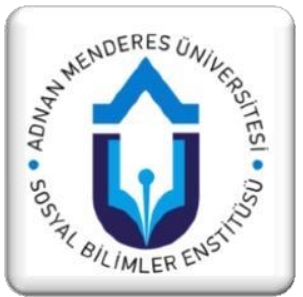

\section{ÖZET}

Teknoloji firmaları tarafindan sürekli güncellenerek ve özellikler eklenerek tüketicilerin beğenisine sunulan cep telefonları ve diğer mobil araçlar, günümüz teknolojilerinden vazgeçilemeyenler arasında sayılabilir. Bu gibi araçlar mobil pazarlama kavramının doğmasına, gelişmesine ve pazarlama için de tüketicilere ulaşmanın kolay yollarından biri haline gelmiştir. $\mathrm{Bu}$ çalışma, üniversite öğrencilerinin, mobil pazarlama kavramına yönelik tutumlarını ölçmeyi hedeflemektedir. Elde edilen bulgulara göre, genç tüketicilerin mobil pazarlamaya yönelik tutumlarını belirleyen başlıca faktörler; eğlendirme, bilgilendirme, rahatsız etme, güvenilirlik, genel tutum, izinli pazarlama ve kişiselleştirilmiş pazarlama olarak belirlenmiştir. Öğrencilerin mobil pazarlamaya karşı tutumu genel anlamda olumsuzdur. Öğrenciler, bu reklamları eğlendirici ve güvenli bulmamaktadır. Bu reklamlar izinli ve bilgilendirilmeye yönelik yapıldığında daha olumlu tutumla karşılanmaktadır. Fakat kesinlikle rahatsız edici bulunmaktadır. Genç tüketicilere karşı izinli ve kişiselleştirilmiş pazarlamaya yönelik çalışmalar, mobil pazarlamaya yönelik tutumları olumlu anlamda destekleyebilir.

Anahtar Kelimeler: Mobil Pazarlama, Mobil Reklâmc1lık, Tüketici Tutumları.

\section{The Effects of Mobile Marketing Activities on Consumer Perception: A Research on University Students}

\begin{abstract}
The mobile phones and other mobile devices which are presented by tech companies with updates and added features, are one of Recent technologic essentials. Such devices gave rise to term "Mobile marketing" and for marketing, became one of the most easy ways to reach the customers. This work aims to measure the attitude of university students about mobile marketing. According to the data acquired, main factors that defines attitude of young consumers on mobile marketing are set as entertainment, acknowledgement, irritation, reliability, general attitude, permitted marketing and personalized marketing. General attitude of students on mobile marketing is adverse. They dont find this advertisements entertaining and reliable. If this advertisements are done by permission and aim to inform, attitude on them becomes more positive, but definitely irritative. Research on permitted and personalized marketing on young consumers, can support positive attitude on mobile marketing.
\end{abstract}

Key Words: Mobile Marketing, Mobile Advertising, Consumer Attitudes.

1 Yrd. Doç. Dr., Adnan Menderes Üniversitesi, Nazilli IİBF İşletme Bölümü, Yönetim ve Organizasyon ABD., mdoganer@adu.edu.tr

2 Doktora Öğrencisi, Adnan Menderes Üniversitesi, Sosyal Bilimler Enstitüsü, İşletme ABD., yaseminyildiz85@hotmail.com 


\section{Giriș}

Gün geçmiyor ki teknoloji sayesinde hayatımız eskiye nazaran gelişme ivmesi kaydetmesin. Değişim hızının artan oranda bir seyir izlemesi, dinamik çevrede faaliyet gösteren ve açık sisteme entegre yaşamak zorunda olan işletmelerin de merceği altında bulunmaktadır. Özellikle talebin arzı tetiklediği bir zincir üzerinde işletmelerin, ürettikleri mal ve hizmetleri doğru yerde, doğru zamanda ve doğru hedef kitleye ulaştırmaları, sistemin kilit noktasını oluşturmaktadır.

Günümüz teknolojisi mobil araçları vazgeçilmez bir unsur haline getirmiştir. Bu araçların özelinde cep telefonu, şüphesiz nihai tüketicilere ulaşma açısından, pazarlama birimlerinin dikkatini çeken ve doğru kullanıldığında işletmelere rekabet üstünlüğü sağlayan önemli bir faktör konumundadır.

Geleneksel pazarlamaya yeni bir soluk getiren mobil pazarlama sayesinde işletmeler, diğer pazarlama yöntemlerine göre hedef kitlelerine daha hızlı ulaşabilmekte ve daha etkin sonuçlar elde edebilme imkanına kavuşabilmektedirler.

Mobil pazarlama özelinde incelenen kısa mesaj hizmetleri (SMS), potansiyel müşterilere ulaşmanın yanı sıra, mevcut müşterileri de elde tutma amacına yönelik olması açısından irdelenmeye ve tartışılmaya değerdir.

Çalışma teorik çerçeve ve uygulama olarak iki bölümde incelenmektedir. İlk bölümde mobil pazarlama genel başlığı altında mobil reklamlar ve mobil reklamcılığa karşı tutumlar ile ilgili bilgilere yer verilmiştir. İkinci bölümde ise Pamukkale Üniversitesi’nde okuyan öğrenciler üzerinde uygulanan anket çalışması sonucu elde edilen veriler ve bunların değerlendirmelerine yer verilmiştir.

\section{Teorik Çerçeve}

\subsection{Mobil Pazarlama}

Günümüzde işletmeler mobil pazarlama ile çevreye uyum sağlamak, sonunda entropiye uğramamak ve en nihayetinde rekabet üstünlüğü sağlayabilmek adına müşterileriyle daha hızlı iletişim kurabilmek imkanına sahip olabilmektedirler.

Mobil pazarlama, büyüyen bir öneme ve ilgiye sahip bir husustur. Mobil pazarlamanın etkililiğine dair kanıtlar halen az olsa da, dünya sathındaki pazarlamacılar mobil medya üzerindeki pazarlama aktivitelerine giderek artan oranda harcama ayırmaktadırlar. $\mathrm{Bu}$ genelde, pazarlama harcamalarının hızla değişen iletişim ortamında, daha iyi geri dönüş sağlamasını isteyen firmaların, bunun için yeni yollar arayışında olduğunun ispatıdır. Kitlesel piyasalar parçalıdır, bu yüzden kişisel olmayan kitlesel iletişim, özellikle medya reklamları, daha etkisizleşirken, birebir pazarlama iletişimi daha önemli hale gelmiştir (Leppäniemi and Karjaluoto, 2008:50).

Mobil pazarlama; mal, hizmet ve fikirlerin tutundurulmasında mobil telefonların kullanılarak yapılan pazarlama çabaları, mobil telefonları aracılığıyla çeşitli iletişim ve tutundurma faaliyetlerinde bulunulması, işletmeyle ilgili tüm çıkar gruplara faydası olacak şekilde mobil telefonlar aracılığıla malların, hizmetlerin ve fikirlerin tutundurulması ile ilgili faaliyetler ve mobil telefonlar yoluyla hedef müşterilerle pazarlama iletişiminin kurulması ve tutundurma yönlü mesajların gönderilmesi olarak tanımlanabilir (Barutçu ve Öztürk Göl, 2009:26). 
Mobil pazarlamanın sahip olduğu özellikleri; (1)doğrudan pazarlama anlayışına sahip olma, (2)maliyetinin düşük olması, (3)ölçülebilir olması, (4)interaktif olması, (5)kişileştirmeye olanak sağlaması, (6)hızlı olması ve (7)farkındalık sağlaması gibi sıralanabilir (Güven Yeşildağ, 2016:19-20).

Geleneksel kitle iletişimi ile karşılaş̧ırıldığında mobil pazarlama; etkileşim, kişiselleştirme imkanı, yer ve durum bağl11 $\breve{g} 1$, hedeflenen müşteriye yönelme, hızlı işlem ve kampanya etkinliğini ölçme imkanı verir (Akbıyık vd. 2008:3).

\subsection{Mobil Reklamlar ve Mobil Reklamcılığa Karşı Tutumlar}

Artan SMS servislerinin sayısı, mobil reklam adı verilen yeni bir reklam mecrası oluşmasına sebep olmuştur. Cep telefonlarının kullanım oranının yüksek oluşu, taşınabilir cihazların mobil ticaretin yönetiminde daha çok kullanılmasına sebep olmuştur. Mobil ticaret uygulamalarının önemli bir parçası olan Mobil reklamlar, İnternetin interaktivite ve hızlı geri dönüş kabiliyetlerine dayanarak, gelecek vadeden bir direkt pazarlama kanalına dönüşmüştür. Özellikle kısa mesaj servisleri, başarılı olmuştur (Xu, 2006-2007: 9).

Mobil pazarlamada yaşanan yeni gelişmeler, her geçen gün beraberinde, araştırmacılara bu mecrada uygulanabilecek reklam faaliyetleri ile ilgili cevaplanması gereken yeni araştırma soruları sunmaktadır. Bu bağlamda, tüketicilerin, \% 90'ının alıcılar tarafından 3 dakika içinde okunduğu ve mobil reklamcılığın çevrimdışı olma özelliğine sahip tek formatı olan SMS reklamlarına yönelik tutumlarının anlaşılması, yeni reklam mekanizmalarının geliştirilmesine ve bu yolla mobil reklamların daha etkin kullanımına yardımcı olacağ düşünülmektedir (Ergin vd., 2016:20).

Eylül 2016 sonu itibarı ile Türkiye'de yaklaşık \%94,6 penetrasyon oranına karşıllı gelen, 'Makineler Arası İletişim (M2M)' aboneleri dahil toplam 74.457.474 mobil abone bulunmaktadır (BTK, 2016/3:39).

Mobil iletişim cihazlarının yüksek kullanım oranları, mobil pazarlamanın büyük potansiyelinin göstergelerinden sadece biridir (Bauer and Barnes, 2005:181). İnternet ortamının uzantısı olan cep telefonlarının son yıllardaki yüksek kullanım oranı, mobil reklamlar için iyi bir firsat yaratmıştır (Chowdhury et al, 2006: 36).

SMS ve MMS sayıları çeyrekler itibariyle incelendiğinde; 2016 yılı üçüncü üç aylık dönemde SMS sayısının yaklaşık 25.718 milyon, MMS sayısının ise yaklaşık 21,8 milyon civarında gerçekleştiği görülmektedir (BTK, 2016/3: 53).

Cep telefonları, alıcının aldığı mesaja anında cevap verebilmesini sağlayan yüksek etkileşimli bir mecradır (Bauer and Barnes, 2005:182). Cep telefonları tamamen kişisel bir cihaz olduğu ve istenilen kişiye neredeyse her şartta ve zamanda ulaşılmasına imkan verdiği için, mobil reklamlar daha kişiselleştirilmiş olmalıdır ve farklı şekiller almaktadır. Farklı stratejik uygulamalara göre, kablosuz pazarlama izin tabanlı, teşvik tabanlı ya da bölge tabanlı olabilir (Chowdhury et al, 2006: 36).

Mobil reklam, işletmelerin mobil iletişim araçları üzerinden kablosuz interaktif medyayı kullanarak, mevcut ve potansiyel müşterilerine ulaşmalarını ve onlara kişiselleştirilmiş bilgilerle mal, hizmet ve fikirler sunmalarını sağlayan bir sistemdir (Kılıç ve Ünver, 2017:40).

Tutum; bir bireye atfedilen ve onun bir psikolojik obje ile ilgili duygu, düşünce ve davranışlarını düzenli bir şekilde oluşturan bir eğilimdir (Kağıtçıbaşı, 2008:110). Başka bir ifadeye göre ise (Silah, 2005:307); bir nesne ya da olaylara karşı sürekli olarak aynı biçimde davranmaya yol çan öğrenilmiş eğilim olarak tanımlanabilir. 
Reklamlara yönelik tutum, genel olarak reklamlara karşı sürekli olarak olumlu veya olumsuz manada karşılık veren öğrenilmiş yatkınlık olarak tanımlanır. Tüketicilerin reklamlara karşı tutumları, özel reklamlara karşı tutumlarını da etkileme eğilimindedir (MacKenzie and Lutz, 1989:53-54).

2002 yılında Tayvan'da 380 (yüksek oranda genç tüketici) kişinin katılımıyla yapılan çalışmada, tüketicilerin mobil reklamlara karşı olan tutumları genel anlamda olumsuz olarak değerlendirilmiştir. Reklamların izin tabanlı olarak gönderildiğinde, tüketici davranışlarının olumluya döndüğü, yapılan çıkarımlar arasındadır. Bu bağlamda, izin tabanlı reklamcıllı̆ın ileride mobil ortamda yapılacak olan reklamcılıkta önemli bir etmen durumuna gelebileceği vurgulanmıştır. Ayrıca genel tutumu etkileyen başlıca etmenler eğlendirme, bilgilendirme, rahatsız etme ve güvenilirlik olarak belirlenmiştir. Bu etmenlerden eğlendirme, bilgilendirme ve güvenilirlik unsurlarının genel tutum üzerinde olumlu, rahatsız etme unsurunun ise olumsuz bir etkisinin olduğu ifade edilmektedir. Genel tutumun üzerinde pozitif olarak etkili olan başka bir unsur da ödül tabanlı reklamcılık olarak kayıtlara geçmiştir (Tsang et al, 2004:65-78).

Armağan ve Bayram (2016) çalışmalarında, mobil pazarlama çerçevesinde mobil cihazların bir pazarlama aracı olarak kullanılmasıyla beraber, bu alanda kullanılan QR kod teknolojisini konu edinmişlerdir. QR kod, herhangi bir mobil cihazın kamerası tarafından kolayca taranabilen iki boyutlu dijital görüntü olarak tanımlanmaktadır. Nazilli'de 18 yaş üzeri 218 tüketici üzerinde yapılan anket çalışması ile veriler elde edilmiştir. Çalışmada, QR kodların günümüz Türkiye'sinde beklediği ilgiyi göremediği ve QR kod farkındalığının gelişmiş ülkelerin kısmen gerisinde kaldığı sonucuna ulaşılmıştır.

\section{Uygulama}

\subsection{Araştırmanın Amacı ve Yöntemi}

Bu çalışmanın temel amacı, Üniversite öğrencilerinin mobil pazarlamaya karşı tutumlarını belirlemektir. Elde edilecek olan bulguların, pazarlama dünyasında mobil pazarlamayı kullanmayı amaçlayan işletmelere yol göstereceği düşünülmektedir.

Anket iki bölümden oluşmaktadır. Birinci bölümünde üniversite öğrencilerinin mobil pazarlamaya karşı tutularını ölçmek için 21 soruluk ölçek ifadesi bulunmadır. Anket soru formunun oluşturulmasında literatürdeki diğer çalışmaların yanında özellikle Tsang ve arkadaşları (2004) tarafından yapılan çalışma dikkate alınmıştır. Anket formundaki faktörlere ilişkin ifadeler 5'li likert ölçeğine göre yapılmıştır ve "1 kesinlikle katılmıyorum" ve "5 kesinlikle kat1lıyorum" anlamını ifade etmektedir.

Anketin ikinci bölümündeki ilk soru, öğrencilerin cinsiyetini belirlemeye yöneliktir. Cinsiyetin mobil reklamlara karşı olan tutumlarını ölçmede, bu bilgi kullanılacaktır. Devam eden sorularda bir ayda alınan mobil reklam sayısı sorulmuş ve mobil reklam alındığındaki tutumlarını belirlemeye yönelik sorular yer almıştır. Bu sorulara karşı tamamen olumsuz bir tavır sergileyenlerin (örneğin "hiç okumam" ifadesini işaretleyenlerin) analizden çıkarılması amaçlanmıştır.

Cronbach's Alpha, sorular arası korelasyona bağlı uyum değeridir. Cronbach's Alpha değeri faktör altındaki soruların toplamdaki güvenilirlik seviyesini göstermektedir. Değerim 0,70 ve üstü olduğu durumlarda ölçeğin güvenilir olduğu kabul edilmektedir. (Durmuş vd, 2016:89). 
Araştırmamızda Cronbach alfa katsayısı 0,865 olarak bulunmuştur. Bu değer, ölçeğimizin güvenilir olduğunu teyit etmektedir.

\subsection{Araştırmanın Modeli}

Araştırmanın modeli şekil 1'de gösterildiği gibi belirlenmiş olup, Tsang ve diğerleri (2004)'nin çalışması esas alınarak hazırlanmıştır.

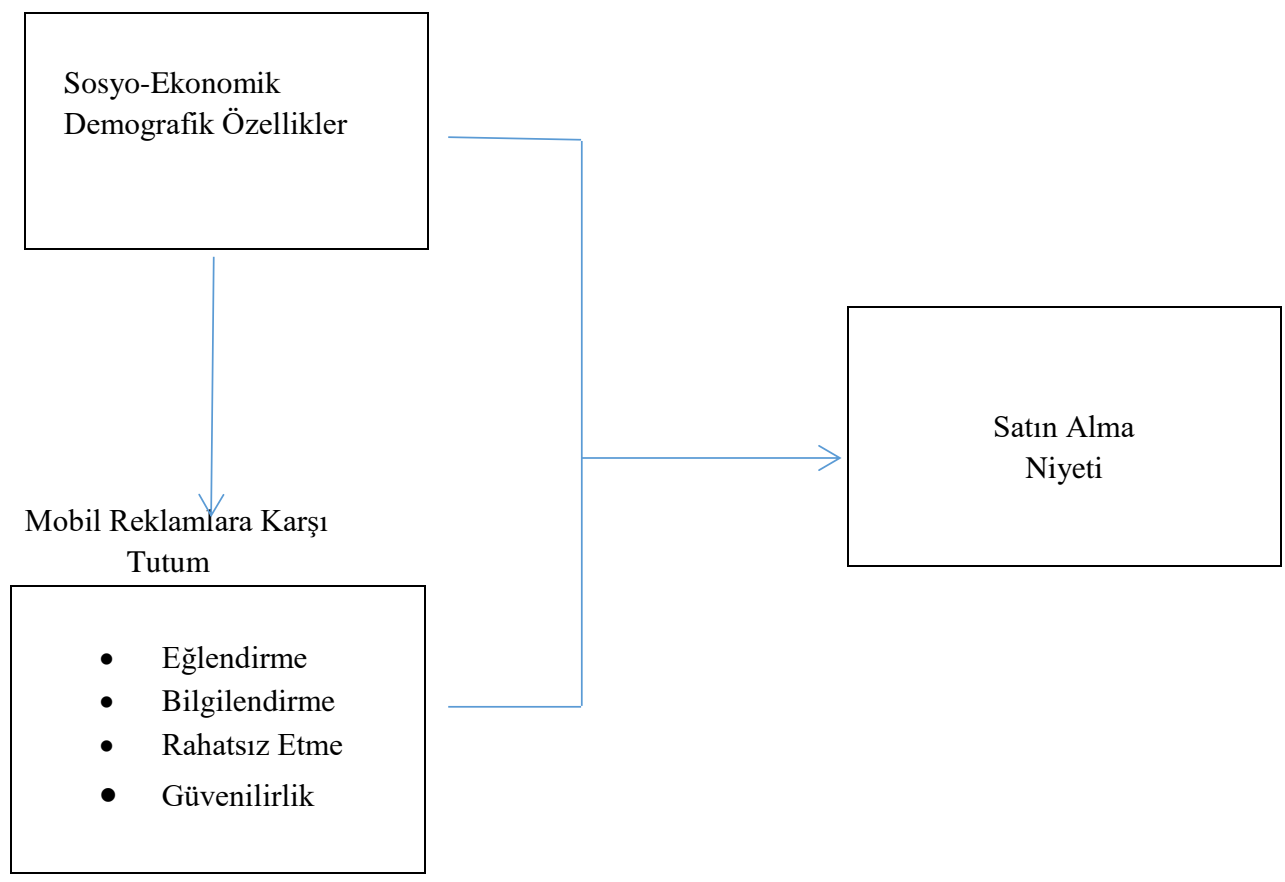

Şekil 1. Araştırmanın Modeli

\subsection{Araştırmanın Hipotezleri}

1) $\mathrm{H}_{1}$ : Tüketicilerin demografik özellikleri ile mobil reklamlara karşı tutum boyutları arasında anlamlı bir ilişki vardır.

$\mathrm{H}_{11}$ : Cinsiyet ile tüketicilerin mobil reklamlara karşı tutum boyutları arasında anlamlı bir ilişki vardır.

$\mathrm{H}_{12}$ : Medeni durum ile tüketicilerin mobil reklamlara karşı tutum boyutları arasında anlamlı bir ilişki vardır.

$\mathrm{H}_{13}$ : Yaş ile tüketicilerin mobil reklamlara karşı tutum boyutları arasında anlamlı bir ilişki vardır.

$\mathrm{H}_{14}$ : Öğrenim durumu ile tüketicilerin mobil reklamlara karşı tutum boyutları arasında anlamlı bir ilişki vardır.

$\mathrm{H}_{15}$ : Gelir ile ile tüketicilerin mobil reklamlara karşı tutum boyutları arasında anlamlı bir ilişki vardır. 
2) $\mathrm{H}_{2}$ : Tüketicilerin sosyo-demografik özellikleri ile satın alma niyeti arasında anlamlı bir ilişki vardır.

$\mathrm{H}_{21}$ : Cinsiyet ile tüketicilerin satın alma niyeti arasında anlamlı bir ilişki vardır.

$\mathrm{H}_{22}$ : Medeni durum ile tüketicilerin satın alma niyetileri arasında anlamlı bir ilişki vardir.

$\mathrm{H}_{23}$ : Yaş ile tüketicilerin satın alma niyetleri arasında anlamlı bir ilişki vardır.

$\mathrm{H}_{24}$ : Öğrenim durumu ile tüketicilerin satın alma niyetlti arasında anlamlı bir ilişki vardir.

$\mathrm{H}_{25}$ : Gelir ile ile tüketicilerin satın alma niyetleri arasında anlamlı bir ilişki vardır.

3) $\mathrm{H}_{3}$ :Tüketicilerin mobil reklama karşı tutum boyutları ile satın alma niyetleri arasında anlamlı bir ilişki vardır. 


\subsection{Araștırmanın Analizi ve Yorumlanması}

\subsection{1. Örnek Kitlenin Özellikleri}

Anketler Mayıs 2016'da, farklı günlerde Pamukkale Üniversitesi merkez kampüse gidilerek gerçekleştirilmiştir. Pamukkale Üniversitesi resmi internet sitesi (www.pau.edu.tr)' nden alınan verilere göre, 2016-2017 eğitim öğretim yılı öğrenci sayıs1 59.015'tir Söz konusu rakamın 19.912'sini meslek yüksekokulları öğrencilerinin oluşturması itibariyle, örneklemimize konu olan rakam 39.103 olarak gerçekleşmiştir. 410 kadar anket çalışması yapılmış, bunlardan 30'u eksik bilgi nedeniyle elenmiş, anket yeterli görülen sayıya tamamlanmak adına 4 anket çalışması daha yapılmıştır. Ana kütle sayısının bilinmediği durumlarda değerlendirilecek örneklem büyüklüğüne yönelik örneklem sayısı minimum 384 (Altunışık vd, 2007:127) olduğundan dolayı, anket çalışması söz konusu sayıya tamamlanmıştır. Araştırma tek bir üniversitede gerçekleştirilmiş olsa da, sonuçların Türkiye geneli üniversite öğrencilerini ve buna bağlantılı olarak genç nesil tüketicileri de temsil edeceği düşünülmektedir. Analizler SPSS 22 programı aracılığıyla yapılmıştır.

Tablo 1. Örneklem Kitlede Bulunan Özellikler

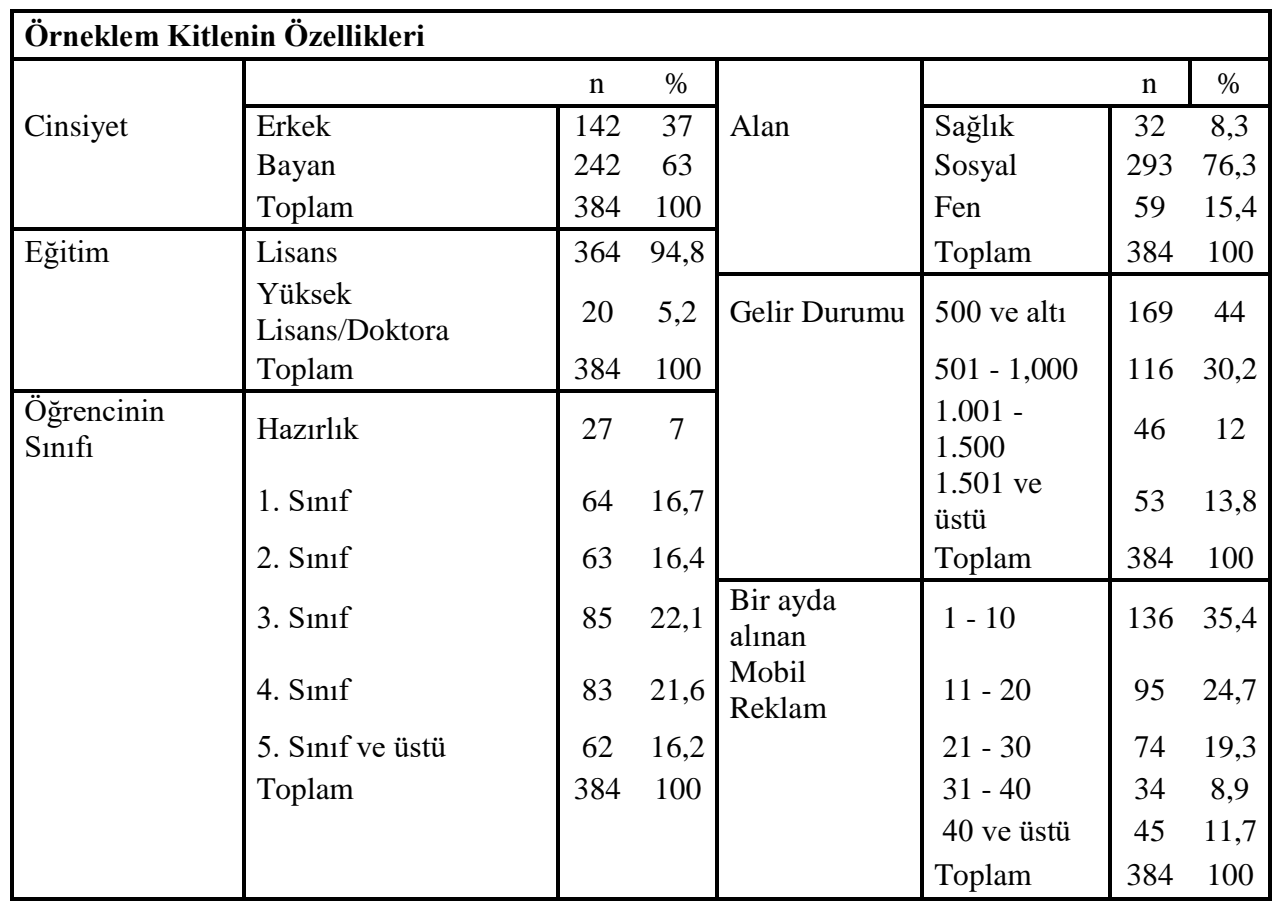

Örnek kitleye ait özellikler Tablo 1'de görüldüğü üzeredir. Çalışmaya katk1 sağlayan 384 öğrencinin \%63'ü bayan, \% 37'si erkektir. Söz konusu örneklemin \% 94,80'i lisans, \% 5,20'si yüksek lisans öğrencilerinden oluşmaktadır. Öğrencilerin sinıflara göre dağglımları incelendiğinde \% 7'si hazırlık, \% 16,70'i 1. Sinıf, \% 16,40'1 2. Sinıf, \% 22,10'u 3. Sinıf, \% 21,60 '1 4. Sınıf ve \% 16,20'si 5.sınıf ve üstü olarak ayrım göstermiştir. Gelir durumlarına göz attığımızda; öğrencilerin neredeyse yarı orana yakınının (\% 44) 500 tl ve altında geliri bulunmaktadır. Bir ayda aldıkları mesaj miktarını 1-10 arası olarak işaretleyenlerin oranı ise $\% 35,40$ olarak belirlenmiştir. 


\subsubsection{Faktör Analizi}

Üniversite öğrencilerinin mobil reklamcılığa karşı olan tutumlarını belirlemek adına, ölçeği oluşturan ifadeleri gruplandırmak ve az sayıda temel boyuta indirgeyerek özetlemek amacıyla, açıklayıcı faktör analizi uygulanmıştır. Ölçekteki ifadelerin faktör analizine uygunluğu Kaiser-Meyer-Olkin (KMO) indisi ile ölçülmüştür. KMO 0.5-1.0 aras1 değerler araştırma için uygun olup, analizimizde bu oran 0,826 olarak bulunmuştur (Altunışık vd, 2005:212-231; Durmuş vd, 2016:73-89). Bartlett Küresellik Testinde ise 0,000 değerli bir anlamlılık elde edilmiş olup, değişkenler arasında faktör analizi yapmaya elverişli bir düzeyde ilişki olduğu kanısına varılmıştır.

Tablo 2. Mobil Reklamcılı̆̆a Karşı Tutumu Etkileyen Faktörler ve Analizleri.

\begin{tabular}{|c|c|c|c|}
\hline $\begin{array}{c}\text { Faktör } \\
\text { Adı }\end{array}$ & İfadeler & $\begin{array}{l}\text { Faktör } \\
\text { Yükü }\end{array}$ & $\begin{array}{c}\text { Faktör } \\
\text { Açıklayıcılığı (\%) }\end{array}$ \\
\hline \multirow{3}{*}{ 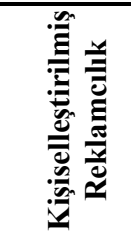 } & Mobil reklam içerikleri kullanımım için kişiselleştirilmiştir. & ,883 & \multirow{3}{*}{30,947} \\
\hline & Mobil reklam içerikleri kişiselleştirilmiştir. &, 861 & \\
\hline & $\begin{array}{l}\text { Mobil reklamlarının benim için kişiselleştirilmiş mesajlar } \\
\text { içerdiğini düşünüyorum }\end{array}$ & ,760 & \\
\hline \multirow{3}{*}{ 音 } & İznim alınarak gönderilen mobil reklamlarını dikkatlice okurum & ,876 & \multirow{3}{*}{11,305} \\
\hline & İznim alınarak gönderilen mobil reklamlarından memnun olurum &, 869 & \\
\hline & İznim alınarak gönderilen mobil reklamlarına güvenirim & ,863 & \\
\hline \multirow{2}{*}{ 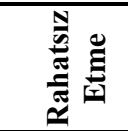 } & Mobil reklamlarını "aldatmaya yönelik" buluyorum & ,897 & \multirow{2}{*}{10,219} \\
\hline & Mobil reklamlarını "can sıkıcı" buluyorum &, 887 & \\
\hline \multirow{2}{*}{ 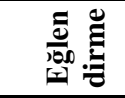 } & Mobil reklamı almanın uygun olduğunu düşünüyorum & ,839 & \multirow[t]{2}{*}{6,701} \\
\hline & Mobil reklamlarını keyifli ve eğlenceli buluyorum & ,827 & \\
\hline \multirow{2}{*}{ 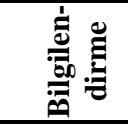 } & Mobil reklamları güncel ürün bilgileri için iyi bir kaynaktır &,- 882 & \multirow{2}{*}{6,534} \\
\hline & Mobil reklamları ilgili olduğum ürünlerin bilgilerini içeriyor &,- 877 & \\
\hline \multirow{2}{*}{ 焉 } & $\begin{array}{l}\text { Mobil reklamlarını kullanan ürünler reklamda iddia edildiği } \\
\text { kadar iyidirler. }\end{array}$ &,- 829 & \multirow[t]{2}{*}{5,468} \\
\hline & $\begin{array}{l}\text { mobil reklamlarını kullanan ürünler ortalamanın üzerinde } \\
\text { kaliteye sahiptir. }\end{array}$ &,- 822 & \\
\hline \multirow{3}{*}{ 童 } & Mobil reklamlarını satın alma için referans olarak kullanırım & ,882 & \multirow{3}{*}{4,419} \\
\hline & Mobil reklamlarından etkilenirim & ,636 & \\
\hline & Mobil reklamlarına güvenebilirim &, 525 & \\
\hline \multicolumn{3}{|l|}{ Toplam } & 75,593 \\
\hline \multicolumn{3}{|c|}{ Cronbach Alpha Değeri (17 değişken için) } &, 818 \\
\hline \multicolumn{3}{|c|}{ Kaiser-Meyer-Olkin (KMO) Örneklem Yeterliliği (17 değişken için) } & ,826 \\
\hline \multicolumn{3}{|c|}{ Bartlett Küresellik Testi } & 2418,929 \\
\hline
\end{tabular}

Faktörler: (1) Kişiselleştirilmiş Reklamcılık, (2) İzinli Reklâmcılık, (3) Rahatsız Etme, (4) Eğlendirme, (5) Bilgilendirme, (6) Genel Tutum, (7) Güvenilirlik.

Tablo 2' de belirtilen faktör analizi sonuçları; genç tüketici neslinin mobil reklamcılığa karşı olan tutumlarını irdelemek adına oluşturulmuştur. Söz konusu tabloyu oluşturmak adına, 17 ifade ve bu ifadeleri gruplandırmak üzere 7 faktör kullanılmışır. Tabloda yer alan sıraya 
göre bu faktörler; kişiselleştirilmiş reklamcılık, izinli reklamcılık, rahatsız etme, eğlendirme, bilgilendirme, genel tutum ve güvenilirlik faktörleridir. On sekiz ifadeden bir tanesi diğer faktörlere benzer oranda yüklendiğinden ölçekten çıkartılmıştır. Yedi faktör, toplam varyansın \% 75,593 ünü açıklamaktadır. Gruplara ayrılmış faktör isimleri, literatür göz önüne alınarak ifade edilmiş olup, aşağıda kısaca bilgiler verilecektir.

\section{Kişiselleştirilmiş Reklamcılık}

Mobil reklamcılık, mobil ortamlarda etkin ve verimli tanıtım yapmak için reklam verenlere, kişiselleştirme gibi özel niteliklere sahip olması nedeniyle yeni firsatlar sunmasıyla dikkat çekmiştir (Xu, 2007:10). Kişiselleştirilmiş reklamcıllk, tüketicilerin neyi bilmek istedikleri, neyi satın almak istedikleri ve nasıl satın almak istedikleri gibi belirli ölçümlere sahip olmayı gerektirir (Pavlou and Stewart, 2000:67).

Her durumda, tüketiciler mobil hizmetin içeriğinin onlarla ilgili ve alâkalı olarak özelleştirilmesini isterler. Kişiselleştirme, pazarlamacıların potansiyel müşterilerine çok farklı şekillerde ulaşmasını ve bu yolla tüketici ile olan ilişkisini artırmasını sağlayabilir (Xu, 2007:10).

\section{İzinli Rekmalcılık}

Mobil telefonların kişisel ve özel cihazlar olmalarından dolayı mobil reklamcılık daha kişisel olarak değerlendirilmelidir ve farklı stratejilerle birlikte düşünülmelidir. Bu stratejilerden bir tanesi "izin temelli reklamcılıktır". İzin temelli reklamcılık, geleneksel metin bazlı rahatsız edici reklamcılıktan farklıdır. İzin temelli reklamcılıkta, belli ürünler ve hizmetlere ilişkin bilgiler, gönderimine izin veren bireylere gönderilmektedir (İspir ve Suher, 2009:9).

Mobil pazarlama uygulamalarının hayata geçirilmesinde izinli pazarlama yaklaşımının temel alınması, başarının etkinliği açısından olumlu katkılar sunacaktır (Akbıyık vd., 2008:8).

\section{Rahatsız Etme}

Mobil reklâmlar da, mesajlarla tüketiciyi etkilemenin yanında, bir dizi yanıltıcı ve oyalayıcı bilgiyi de içerebilirler. Yanıltıldığını hisseden tüketiciler, negatif tutum gösterirler (Usta, 2009:303). Genel olarak bakıldığında genç tüketicilerin mobil reklamlarının alımına yönelik olumsuz tutumları olduğu görülmektedir. Bunun temel sebebi mobil telefonların kişisel ve özel cihazlar olmalarından dolayı Mobil reklamlarını rahatsız edici bulmaları olabilir. Mobil reklamı alımına izin verme söz konusu olduğunda, çok fazla olmamakla birlikte tutumlar olumluya doğru yönlenmektedir (İspir ve Suher, 2009:15).

\section{Eğlendirme}

Mesajın özlü ve komik olması çok önemlidir (Zia, 2009:213). Geleneksel ve internet reklâmcılığında olduğu gibi tüketicilerin mobil reklâmlara karşı tutumlarının belirleyicilerinden birincisi, reklâmların eğlendiricilik özelliğidir. Tüketiciler tarafından veciz ve komik algılanan mesajlar ilgi çeker ve tüketici bağl1lı̆̆ yaratır. İnsanların çoğu ve özellikle de çocuklar ve gençlerin doğasında oyun oynama isteği vardır. Bu nedenle, eğlenceli oyunlar içeren mesajlar yüksek katılım sağlar (Usta, 2003:303). 


\section{Bilgilendirme}

Mobil cihazlar aracığıyla müşterilere iletilen bilgiler, doğruluk, güncellik ve tüketici için kullanışlılık gibi nitelikleri göstermelidir. Ayrıca, kullanıcıların, kullanım şekillerine göre aradıkları bilgiye hızlı ulaşmada da ihtiyaçları vardır (XU, 2006-2007:11). (Chowdhurry et al, 2006) çalışmalarında, reklam mesajının bilgi içeriğinin, tüketicilerin reklama karşı tutumlarını olumlu yönde etkilediği sonucunu çıkarmışlardır.

\section{Güvenilirlik}

Müşteri güveni, mobil ticaretin büyümesi ve başarısı için hayatidir. Çünkü; güven oluşturmak sadece çok vakit almakla kalmaz, aynı zamanda çok kırılgan ve kolayca yıkılabilirdir de. Sürekli güven geliştirme süreci, özel ilgi gerektirir (Siau and Shen, 2003: 93-94).

Mckenzie ve Lutz (1989:51), reklam güvenilirliğini 'reklamda marka ile ilgili savların doğru ve inanılabilir olduğunu düşünülmesi ile ilgili' olduğunu belirtirken; Pavlou ve Stewart (2000:70), 'güvenilirlik, anlaşmanın örtülü ve açık gereksinimlerinin öngörülebilirliği ve yerine getirilmesi ile ilgilidir' ifadesini kullanmışlardır.

Tüketicilerin bir pazarlamacıya olan güveni, tüketicilerin pazarlamacının belirli bir işlemi kendi beklentileri ile tutarlı bir şekilde gerçekleştireceğine inanması ihtimali olarak tanımlanabilir (Pavluo and stewart, 2000:70). Bir reklamın güvenilirliği, farklı faktörlerle, özellikle de şirketin güvenilirliğiyle ve mesajın gönderiliş biçimi ile ilgilidir (Chowdhury et al, 2006:37). 


\subsubsection{Faktörlerin Ortalamaları, Standart Sapmaları ve Güvenilirlik Katsayılarına İlişkin Açıklamalar}

Tablo 3. Faktörlerin Ortalamaları, Standart Sapmaları ve Güvenilirlik Katsayıları

\begin{tabular}{|c|c|c|c|}
\hline Faktörler & Ortalamalar & $\begin{array}{l}\text { Standart } \\
\text { Sapmalar }\end{array}$ & Alfa ( $\alpha$ ) Katsayıları \\
\hline Kişiselleştirilmiş Reklamcılık & 2,35 & 1,17 & \multirow[t]{4}{*}{$\mathbf{0 , 8 3 1}$} \\
\hline $\begin{array}{l}\text { Mobil reklamlarının benim için kişiselleştirilmiş mesajlar } \\
\text { içerdiğini düşünüyorum. }\end{array}$ & 2,28 & 1,15 & \\
\hline Mobil reklam içerikleri kullanımım için kişiselleştirilmiştir. & 2,38 & 1,19 & \\
\hline Mobil reklam içerikleri kişiselleştirilmiş̧ir. & 2,39 & 1,17 & \\
\hline İzinli Reklamcılık & 2,77 & 1,09 & \multirow[t]{4}{*}{$\mathbf{0 , 8 5 2}$} \\
\hline $\begin{array}{l}\text { İznim alınarak gönderilen mobil reklamlarını dikkatlice } \\
\text { okurum }\end{array}$ & 2,8 & 1,27 & \\
\hline İznim alınarak gönderilen mobil reklamlarına güvenirim & 2,72 & 1,22 & \\
\hline $\begin{array}{l}\text { İznim alınarak gönderilen mobil reklamlarından memnun } \\
\text { olurum }\end{array}$ & 2,78 & 1,23 & \\
\hline Rahatsız Etme & 3,28 & 1,17 & \multirow[t]{3}{*}{$\mathbf{0 , 7 5 3}$} \\
\hline Mobil reklamlarını "can sıkıcı" buluyorum & 3,29 & 1,34 & \\
\hline Mobil reklamlarını "aldatmaya yönelik" buluyorum & 3,27 & 1,26 & \\
\hline Eğlendirme & 2,2 & 0,96 & \multirow[t]{3}{*}{0,699} \\
\hline Mobil reklamlarını keyifli ve eğlenceli buluyorum & 1,99 & 1,09 & \\
\hline Mobil reklamı almanın uygun olduğunu düşünüyorum & 2,41 & 1,11 & \\
\hline Bilgilendirme & 2,72 & 1,05 & \multirow[t]{3}{*}{$\mathbf{0 , 7 2 7}$} \\
\hline Mobil reklamları ilgili olduğum ürünlerin bilgilerini içeriyor & 2,67 & 1,01 & \\
\hline Mobil reklamları güncel ürün bilgileri için iyi bir kaynaktır & 2,77 & 1,1 & \\
\hline Genel Tutum & 2,18 & $\mathbf{0 , 8 6}$ & \multirow[t]{4}{*}{0,706} \\
\hline Mobil reklamlarına bakmaktan hoşlanırım & 2,06 & 1,13 & \\
\hline $\begin{array}{l}\text { Mobil reklamlarını kullanan ürünler ortalamanın üzerinde } \\
\text { kaliteye sahiptir. }\end{array}$ & 2,32 & 1,08 & \\
\hline $\begin{array}{l}\text { Mobil reklamlarını kullanan ürünler reklamda iddia edildiği } \\
\text { kadar iyidirler. }\end{array}$ & 2,16 & 1,03 & \\
\hline Güvenilirlik & 2,29 & $\mathbf{0 , 8 9}$ & \multirow[t]{4}{*}{0,685} \\
\hline Mobil reklamlarını satın alma için referans olarak kullanırım & 2,28 & 1,14 & \\
\hline Mobil reklamlarına güvenebilirim & 2,29 & 1,12 & \\
\hline Mobil reklamlarından etkilenirim & 2,3 & 1,15 & \\
\hline
\end{tabular}

Aritmetik ortalamalar, Üniversite öğrencilerinin mobil reklamcıllğa karşı tutumlarını ifade eden genel bir gösterge niteliğindedir. Tablo 3'de, mobil reklamlara yönelik tutum ve tutumu etkileyen faktörlerin ortalamaları incelendiğinde, genel olarak olumsuz bir tutum içinde bulunulduğu görülmektedir. Genel tutum değerinin, nötr olarak kabul gören 3 değerinin altında 2,18 olarak ifade edilmesi, bir önceki cümlede ifade edilmek istenen durumu örneklendirecektir. İzin alınarak veya bilgilendirme amaçlı yapılan reklamlarda 
ortalamaların, diğer faktörlere nazaran daha yüksek olduğu görülmektedir. Fakat göze çarpan önemli bir unsur, mobil reklamların ortalamanın üstünde bir değerle $(3,28)$ rahatsız edici bulunduğudur.

Faktörlerin standart sapma değerleri 0,86 ile 1,17 arasında değişmektedir. Bu değerler arasındaki geçerli varyans miktarı analizi yapmak için uygun görünmektedir. Tüm bunlara ek olarak tüm faktörlere ait Cronbach $\alpha$ katsayıları verilmiştir. Bu güvenilirliklerin seviyesi genel olarak, literatürde çoğunlukla kabul gören 0,70 değerinin üzerinde bir düzeyde olduğu tespit edilmiştir.

\subsubsection{Değişkenlerin Normal Dağılıma Uygunluğu}

Tüm değişkenler tek tek incelenmiş, Tablo 4'te elde edilen bulgular özetlenmiştir. Değişkenlerin normalliği istatistiksel yöntemlerle veya grafik yöntemlerle değerlendirilir. Çarpıklık ve basıklık normal dağılımdaki iki bileşendir (Tabachnick and Fidell, 2007:79). Tabachnick ve Fidell (2007), çarpıklık ve basıklık değerlerinin $+1,500$ ve $-1,500$ değerleri arasında olduğu durumlarda dağılımın normal dağılım olarak gerçekleştiğini kabul etmektedirler. Tabloda sunulan değerler dikkate alındığında, değişkenlere ait çarpıklık ve basıklık değerlerinin $+1,500$ ve $-1,500$ arasında değiștiği görülecektir. Bu değerler, çalışmamızın normal dağılıma uygunluğunu ifade etmektedir.

Tablo.4 Değişkenlerin Çarpıklık ve Basıklık Değerleri

\begin{tabular}{|l|l|r|}
\hline \multirow{2}{*}{ Eğlendirme } & Çarpıklık & İstatistik \\
\cline { 2 - 3 } & Basıklık &, 607 \\
\hline \multirow{2}{*}{ Bilgilendirme } & Çarpıklık &,- 268 \\
\cline { 2 - 3 } & Basıklık &,- 693 \\
\hline \multirow{3}{*}{ Rahatsız Etme } & Çarpıklık &, 306 \\
\cline { 2 - 3 } & Basıklık &,- 748 \\
\hline Güvenilirlik & Çarpıklık &, 303 \\
\cline { 2 - 3 } & Basıklık &,- 405 \\
\hline Genel Tutum & Çarpıklık &, 532 \\
\cline { 2 - 3 } & Basıklık &, 117 \\
\hline İzinli Reklamcılık & Çarpıklık &, 073 \\
\cline { 2 - 3 } & Basıklık &,- 84 \\
\hline Kişiselleştirilmiş & Çarpıklık &, 386 \\
\cline { 2 - 3 } Reklamcllık & Basıklık &,- 439 \\
\hline
\end{tabular}




\subsubsection{T Testi ve One-Way Anova Testi}

Çalışmanın bu bölümünde genç tüketicilerin cinsiyet, medeni durum ve diğer sosyodemografik özelliklerinin mobil reklamlara karşı tutum boyutlarına ve satın alma niyetlerine olan etkilerini belirlemeye yönelik $\mathrm{t}$ testleri ve anova testleri yapılmıştır.

Tablo 5. Cinsiyetin ve Medeni Durumun, Ara Değişken ve Bağımlı Değişkenin Değerlendirilmesine Yönelik T-Testi Sonuçları

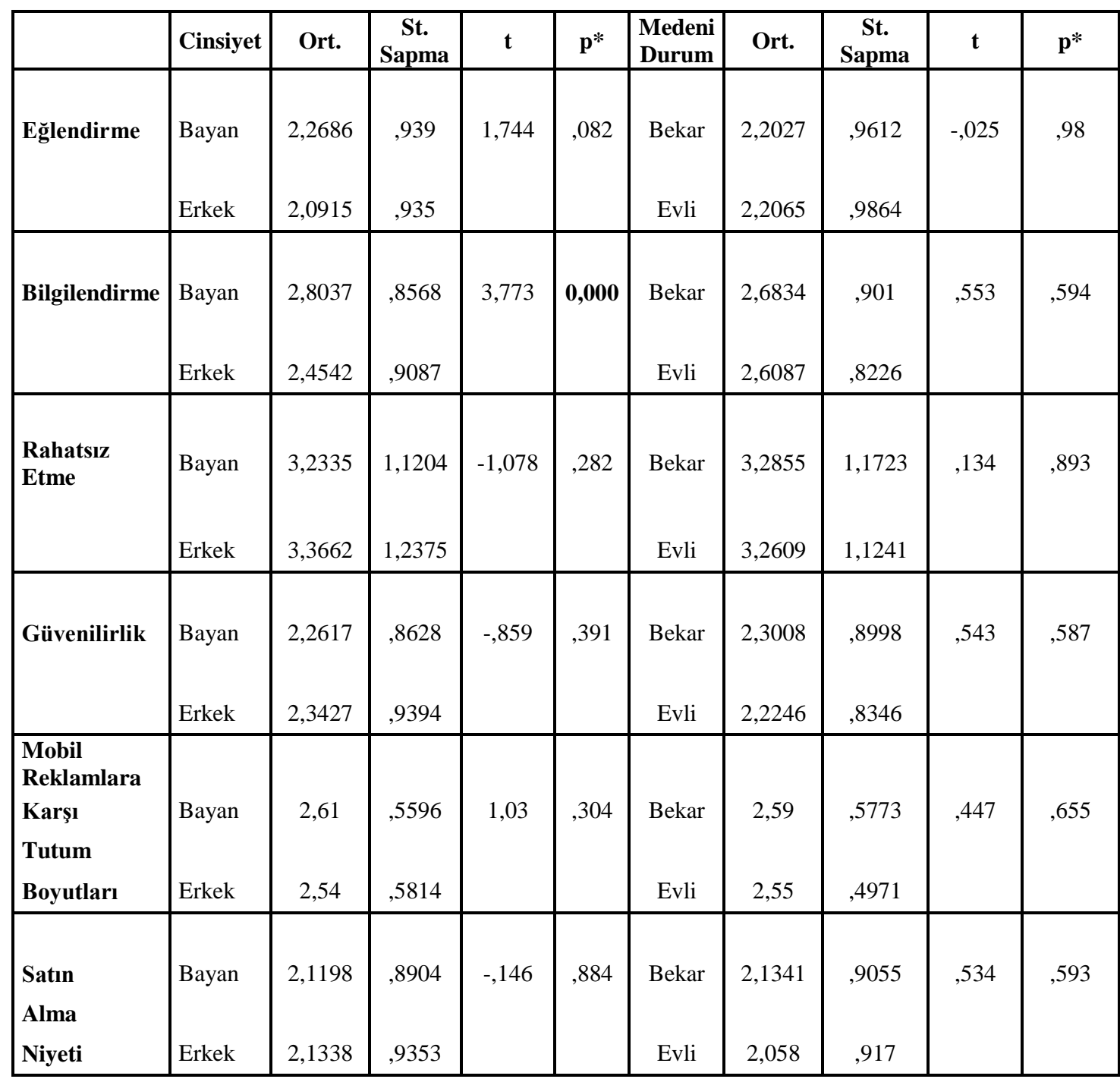

$* \mathrm{p}<0,05$

Mobil reklamlara karşı öğrencilerin tutumlarının ölçüldüğü bu çalışmada, faktörler arasında cinsiyetlere ve medeni durumlara göre farklılık olup olmadığ incelenmiştir. Tablo 5'e göre; cinsiyet ile tüketicilerin mobil reklamlara karşı tutum boyutları ve satın alma niyetleri arasında anlamlı bir ilişki görülmemektedir. Dolayısıyla $\mathrm{H}_{11}$ ve $\mathrm{H}_{12}$ hipotezleri reddedilmiştir $(\mathrm{p}>0,05)$. 
Medeni durum ile de tüketicilerin mobil reklamlara karşı tutum boyutları ve satın alma niyetleri arasında anlamlı bir ilişki bulunmadığından $(\mathrm{p}>0,050), \mathrm{H}_{12}$ ve $\mathrm{H}_{22}$ hipotezleri reddedilmiştir.

Tablo 6. Tüketicilerin Diğer Sosyo-Demografik Özelliklerine Göre Faktörlerin, Ara Değişken ve Bağımlı Değişkenin Değerlendirilmesine Yönelik Anova Testi

\begin{tabular}{|c|c|c|c|c|c|c|}
\hline & \multicolumn{2}{|c|}{ Yaş } & \multicolumn{2}{|c|}{ Öğrenim durumu } & \multicolumn{2}{|c|}{ Gelir } \\
\hline & $\mathrm{F}$ & sig & F & sig & $\mathrm{F}$ & sig \\
\hline Eğlendirme & 0,596 & 0,618 & 3,724 & 0,054 & 0,284 & 0,837 \\
\hline Bilgilendirme & 0,702 & 0,551 & 0,151 & 0,698 & 1,943 & 0,122 \\
\hline Rahatsiz Etme & 3,048 & $\mathbf{0 , 0 2 9}$ & 5,056 & $\mathbf{0 , 0 2 5}$ & 0,442 & 0,723 \\
\hline Güvenilirlik & 0,117 & 0,95 & 0,414 & 0,52 & 3,387 & 0,018 \\
\hline $\begin{array}{l}\text { Mobil Reklamlara } \\
\text { Karşı } \\
\text { Tutum } \\
\text { Boyutları }\end{array}$ & 0,237 & 0,87 & 0,206 & 0,65 & 2,4 & 0,067 \\
\hline Satın alma niyeti & 0,375 & 0,771 & 0,016 & 0,899 & 4,41 & 0,005 \\
\hline
\end{tabular}

$* \mathbf{P}<0,05$

One-Way Anova testine bakıldığında $\mathrm{H}_{13}(0,87>0,050)$ ve $\mathrm{H}_{23}(0,771>0,050)$ hipotezleri reddedilmiştir. Tüketicilerin öğrenim durumunun (düzeylerinin) da mobil reklamlara karşı tutum boyutları üzerinde $(0,65>0,050)$ ve satı alma niyetleri üzerinde $(0,899>0,050)$ anlamlı bir etkisi görülmediğinden $\mathrm{H}_{14}$ ve $\mathrm{H}_{24}$ hipotezleri kabul görmemiştir. Gelir unsurunun mobil reklamlara karşı tutum ile anlamlı bir ilişkisi bulunmadığından $\mathrm{H}_{15}(0,067>0,050)$ reddedilmiştir. Gelir unsurunun satın alma niyeti üzerinde anlamlı bir etkisi olduğundan $\mathrm{H}_{25}(0,005<0,050)$ kabul görmüştür. Tukey testine göre, 1.001-1.500 TL aralığında gelire 
sahip olanların, $500 \mathrm{TL}$ ve altı gelire sahip olanlara göre satın alma niyetlerinde artış olduğunu söyleyebiliriz.

\subsubsection{Mobil Reklamlara Karşı Tutum Boyutları ve Satın Alma Niyeti Arasındaki İlişski}

Satın alma niyetine ve ona etki eden mobil reklama yönelik tutum faktörleri (eğlendirme, bilgilendirme, rahatsı etme ve güvenilirlik) arasındaki ilişkileri test etmek amacıyla Çoklu Regresyon Analizi yapılmıştır.

Bağımsız değişkenlerden ikisi veya daha fazlası arasında kuvvetli doğrusal ilişki olması durumu, çoklu doğrusal bağlılık olarak adlandırılmaktadır. Tam çoklu doğrusal bağlılık olduğunda, sistem çözülememekte, parametreler tahmin edilememekte veya bazı temel varsayımlar geçerli olmamaktadır (Güriş ve Çağlayan, 2013:183).

Çoklu regresyonda tahmin edilecek parametre sayısı k'dır. Gözlem sayısı k'dan az olduğunda parametreler tahmin edilemez, eşit olduğunda da serbestlik derecesi sağlanamaz. Bu nedenle $\mathrm{n}>\mathrm{k}$ olması gerekir. Çoklu regresyonda örneklem sayısı " $\mathrm{N} \geq 50+8 \mathrm{x}$ bağımsız değişken sayısı" ile hesaplanır (Tabachnick and Fidell 2007: 123). Çalışmamızda 384 anket kullanımı, gözlem sayısını yeterli kılmaktadır.

Öncelikle değişkenler arasında çoklu bağlantı probleminin var olup olmadığı test edilmiştir. Buna göre değişkenler arasındaki korelasyon katsayılarının 0,90'nin üzerinde olmaması gereklidir (İspir ve Suher, 2009:13). Tablo 7 incelediğinde, katsayıların 0,90' nın altında bir değerde kaldığı görülecektir.

Tablo 7. Değişkenler Arası Korelasyon Katsayıları

\begin{tabular}{|l|c|l|l|l|}
\hline & Bilgilendiricilik & Eğlendiricilik & Güvenilirlik & Rahatsı Edicilik \\
\hline Eğlendiricilik &, $502^{* *}$ & & & \\
\hline Güvenilirlik &, $417^{* *}$ &, $475^{* *}$ & & \\
\hline Rahatsı Edicilik &,$- 169^{* *}$ &,$- 187^{* *}$ &,$- 185^{* *}$ & \\
\hline Satın Alma Niyeti &, $413^{* *}$ &, $498^{* *}$ &, $577^{* *}$ &,$- 850^{* *}$ \\
\hline
\end{tabular}

\footnotetext{
** $\mathrm{p}<0,01$ (çift yönlü)
} 


\subsection{7. Çoklu Regresyon Analizi}

Tablo 8. Çoklu Regresyon Analizi

\begin{tabular}{|c|c|c|c|c|c|c|c|}
\hline & \multicolumn{2}{|c|}{$\begin{array}{l}\text { Standardize Edilmemiş } \\
\text { Katsayilar }\end{array}$} & \multirow{2}{*}{$\begin{array}{c}\text { Standardize } \\
\text { edilmiş } \\
\text { Katsaylar }\end{array}$} & \multirow[b]{2}{*}{$\mathrm{T}$} & \multirow[t]{2}{*}{ Anlamlılık } & \multicolumn{2}{|c|}{$\begin{array}{c}\text { Eş doğrusallık } \\
\text { İstatistikleri }\end{array}$} \\
\hline & $\beta$ & Std. Hata & & & & Tolerans & VIF \\
\hline (Sabit Terim) &, 424 & ,138 & & 3,061 & ,002 & & \\
\hline Eğlendirme &, 233 & ,046 & ,248 & 5,102 & ,000 & ,658 & 1,519 \\
\hline Bilgilendirme &, 127 & ,048 &, 125 & 2,655 & ,008 & ,704 & 1,420 \\
\hline Rahatsız Etme &,- 046 & ,031 &,- 059 & $-1,462$ &, 145 & ,949 & 1,054 \\
\hline Güvenilirlik & ,425 & 047, & ,418 & 9,029 & ,000 &, 725 & 1,378 \\
\hline
\end{tabular}

Tolerans değerinin küçük olması (0,10'un altı) ve VIF değerinin büyük olması (10'un üstü) çoklu bağlantı probleminin var olduğunu gösteren bir işarettir (İspir ve Suher, 2009:13). Bunun için Tolerans ve VIF değerleri kontrol edilmiştir. Tablo 8'deki değerler incelendiğinde görüleceği üzere; Tolerans değerleri 0,65 ile 0,94 aralığında, VIF değerleri ise 1,05 ile 1,51 arasında değişim göstermektedir. Elde edilen değerler, çoklu regresyon analizi varsayımlarından olan çoklu bağlantı problemi olmadığını kanıtlamaktadır. $\mathrm{Bu}$ bağlamda Normallik ve doğrusallık varsayımları test edilmiştir.

Regresyon analizi sonucu elde edilen değerler analiz edildiğinde, bağımsız olan değişkenlerin (eğlendirme, bilgilendirme, rahatsız etme, güvenilirlik) bağımlı değişken (satın alma niyeti) üzerinde, toplam varyansın \% 41'sini (R2:0,411) açıkladığ 1 sonucuna varılmaktadır. Bütünü tamamlamaya ilişkin arta kalan değerleri, modele dahil olmayan diğer değişkenlerin açıklayacağı anlaşılmaktadır.

Tabloya ilişkin değişkenler incelendiğinde rahatsız etme hariç diğer değişkenlerin $(0,05$ anlamlılık düzeyinde) anlamlı olduğu bulgusu elde edilmiştir.

Standardize edilmiş katsayılardaki değişkenlere ilişkin Beta katsayıları incelendiğinde, bağımlı değişken tutumu açıklamaya en çok katkı sağlayan 0,425 ile güvenilirlik değişkenidir. Bunu sırasıyla eğlendirme $(0,233)$, bilgilendirme $(0,127)$ ve rahatsız etme $(-, 046)$ değişkeni takip etmektedir.

Standardize edilmemiş katsayılara bakıldığında sabit terim $\beta$ değeri 0,424 'tür. Eğlendirme bir birim arttığında tutum $0,233(\beta=0,233)$, bilgilendirme bir birim arttığında tutum 0,127 
$(\beta=0,127)$, rahatsız etme bir birim arttı̆ğnda tutum,$- 046(\beta=-, 046)$ ve güvenilirlik bir birim arttığında tutum $0,425(\beta=0,425)$ değerinde bir artış gösterecektir.

Regresyon analizi sonucu $\mathrm{H}_{3}$ hipotezi olan "Tüketicilerin mobil reklama karş1 tutum boyutları ile satın alma niyetleri arasında anlamlı bir ilişki vardır" hipotezi kabul edilebilir. Eğlendirme, bilgilendirme ve güvenilirlik değişkenleri, mobil reklamlara karşı olan tutumu etkilemektedir. Bu etki güvenilirlik ve eğlendirme faktörlerinde daha etkindir.

Armağan ve Gider (2014) Nazilli'deki üniversite öğrencilerine yönelik mobil pazarlama algısı üzerine, 634 anket ile benzer bir çalışma gerçekleştirmişlerdir. Verilere göre \%59,7 oranında öğrenci ilgi alanına giren mobil reklam mesajlarını daha çok dikkate aldığını ifade etmiştir. Söz konusu bulgu, ulaştığımız sonuçlarla benzerlik göstermektedir. Ankete katılanların \%69,7'sinin mobil telefonlarına reklam içerikli mesajların gelmesini eğlenceli buldukları ifadesi ile, genel anlamda öğrencilerin cep telefonlarına gelen reklam mesajlarını ilgi çekici buldukları ve mesajlara olumlu baktıkları sonucu, elde ettiğimiz sonuçlarla örtüşmemektedir. 


\section{Sonuçlar ve Öneriler}

Mobil Reklamcılığa karşı tutumları incelemeye yönelik olan bu çalışmada, tutumu etkileyen faktörlerin neler olduğu literatür 1şı̆̆ında oluşturulmuş ve bu faktörlere yönelik tutum detayları irdelenmeye çalışılmıştır. Genç tüketicileri temsil edebilme özelliğine sahip olabileceği düşüncesiyle örneklem, Pamukkale Üniversitesi lisans ve yüksek lisans öğrencilerinden oluşmaktadır ve analiz söz konusu örneklemin oluşturduğu 384 adet anketten gerçekleştirilmiştir. Mobil reklamcılığa karşı tutumları etkileyen faktörler eğlendirme, bilgilendirme, rahatsız etme, güvenilirlik, genel tutum, izinli pazarlama ve kişiselleştirilmiş pazarlama olarak incelemeye tabi tutulmuştur.

Genç tüketicilerin mobil reklamcılığa karşı tutumları genellikle olumsuzdur. Faktörlere yönelik tutumların ortalamasının bulunduğu tabloda da belirtildiği üzere, mobil reklamlara yönelik tutumlar açısından en yüksek ortalamaya sahip faktör rahatsız etme faktörüdür. $\mathrm{Bu}$ faktörü sırayla izinli reklamcılık, bilgilendirme ve kişiselleştirilmiş reklamcılık izlemektedir. Yani genç tüketiciler olumsuz tutumlarının yanı sıra, kendilerinden ön izin alınarak veya kendilerine bilgi verilen veya ilgi alanlarına yönelik bireyselleştirilmiş olarak yapılan reklamlara daha fazla ilgi göstermektedirler. Bu bağlamda mobil reklamcılığın izinli ve daha fazla kişiselleştirilmiş olarak yapılması, pazarlama açısından olumlu sonuçlar doğuracaktır.

6563 sayılı Elektronik Ticaretin Düzenlenmesi Kanunu 01.05.2015 tarihinden itibaren yürürlüğe girmiş ve izinli pazarlama alanında birtakım ciddi düzenlemelerde bulunmuştur. Söz konusu yasanın 6. Maddesi ile 'Ticari elektronik iletiler, alıcılara ancak önceden onayları alınmak kaydıyla gönderilebilir' buyurmaktadır. Yasa ile izinli reklamcılık mecrasına hatırı sayılır katkı sağlanmış olsa da, konuyla ilgili daha fazla çalışma yapılması, biz tüketicilerin faydasına olacak gibi görünmektedir. Akıllı telefonların yaygınlaşması ile birlikte hat safhaya ulaşan kişiselleştirilmiş pazarlama, hatta ve hatta girdiğimiz alışveriş̧ sitelerinden en son bakılan diye hatırlatılan ürünler, bu alana yönelik sorunlara çözüm olmaya adaydır. Fakat unutmayalım ki aratarak devam etmesine rağmen akıllı telefon sahibi olmayan daha birçok tüketici mevcuttur. Pazar payını artırmak adına ne kadar çok pazar o kadar çok satış, ne kadar çok satış o kadar çok kar fikrinden yola çıkacak olursak, mobil reklamların firmalar açısından önemi geçmişe nazaran azalmış olsa da, dikkatle değerlendirilmesi gereken bir husus olarak görünmektedir.

Elde edilen bulgular, genç tüketicilerin mobil reklamcılığa bakış açılarını genel olarak yansıtmasına rağmen, çalışmada birtakım kısıtlar da bulunmaktadır. Bu kısıtların en önemlilerinden biri, kuşkusuz araştırmanın örneklemi ile ilgilidir. Araştırma üniversite gençliğini kapsamaktadır. Üniversite gençliği yakın yaş gruplarını temsil edebilir fakat diğer yaş gruplarını temsil edemeyebilir. Bu bağlamda, araştırmanın derinliği açısından genel bir tüketici kitlesine yönelik çalışmalar yapılabilir ya da farklı yaş grupları karşılaştırmalı olarak incelenebilir. Kısıtlardan diğeri de, ölçektir. Kullanılan ölçek, yabancı bir kaynaktan uyarlanmıştır. Dolayısı ile çevirinin ifadeye tam olarak karşılık gelemeyebileceği, kısıt unsurunu oluşturan etmenlerdendir. Konu ile ilgili olarak yerli ölçek çalışması da, ihtiyaçlar arasındadır. Ek olarak, bundan sonraki çalışmalara başka bir öneri de, konu ile ilgili daha spesifik çalışmaların yapıılması yönündedir. 


\section{KAYNAKÇA}

AKBIYIK, Adem, OKUTAN, Semih ve ALTUNIȘIK, Remzi (2008). Mobil Pazarlama Platformunda İzinli Pazarlama Uygulamalarına Yönelik Tüketici Tutum ve Algıları Üzerinde Bir araştırma. 13. Pazarlama Kongresi Bildiri Kitabı, Nevşehir, ss.1-9.

ARMAĞAN, Ece \& GIDER, Abdurrahman (2014). Mobil Pazarlama ve Üniversite Öğrencilerinin Mobil Pazarlama Algısı: Nazilli’ deki Üniversite Öğrencilerine Yönelik Bir Araştırma. AJIT-e: Online Academic Journal of Information Technology, 5(17), $27-44$.

ARMAĞAN, Ece \& BAYRAM, Abdullah (2016). Mobil Pazarlama Aracı Olarak QR Kod ve Sunulan QR Kod Önerilerine Dair Tüketicilerin Bakış Açısı. UMYOS, 5th International Vocational Schools Symposium, 1, 344 -354.

BARUTÇU, Süleyman \& GÖL, Meltem ÖZTÜRK (2009). Mobil Reklamlar ve Mobil Reklam Araçlarına Yönelik Tutumlar. KMU IIIBF Dergisi, 11(17), 24-41.

BAUER, Hans H., BARNES, Stuart. J., REICHARDT, Tina, \& NEUMANN, Marcus M. (2005). Driving Consumer Acceptance Of Mobile Marketing: A Theoretical Framework and Empirical Study. Journal of Electronic Commerce Research, 6(3), 181-192.

BTK, (2016). Üç Aylık Pazar Verileri Raporu, 10.05.2017, https://www.btk.gov.tr/File/?path=ROOT/1/Documents/Sayfalar/Pazar Verileri/BTK2016_Q3_15_12_16.pdf.

CHOWDHURY, Humayun Kabir, PARVIN, Nargis, WEITENBERNER, Christian \& BECKER, Michael (2006). Consumer Attitude Toward Mobile Advertising in An Emerging Market: An Emprirical Study. International Journal of Mobile Marketing, $1(2), 33-42$.

DURMUŞ, Beril, YURTKORU, E. Serra \& ÇİNKO, Murat. (2016). Sosyal Bilimlerde SPSS'le Veri Analizi (6.Basım). İstanbul: Beta Basım Yayım.

ERGIN, Taylan Deniz, ESEN, Selin KÜÇÜKKANCABAŞ \& TUZLA, Hayri (2016). Genç Tüketicilerin Karar Verme Stilleri İle SMS Reklamlarına Yönelik Tutumları Arasındaki Farkların İncelenmesi. Yönetim ve Ekonomi Araştırmaları Dergisi, 14(2), 18-40.

GÜRIŞ, Selahattin \& ÇAĞLAYAN, Ebru (2013). Ekonometri Temel Kavramlar. İstanbul: Der Yayıncilik.

GÜVEN YEŞiLDAĞ, Gül N. (2016). Mobil Pazarlama Uygulamalarının Pazarlama Performansı ve Müşteri Memnuniyetine Etkisi: Seyahat Acentaları Üzerine Bir Araştırma. Yayınlanmamış doktora tezi, Beykent Üniversitesi Sosyal Bilimler Enstitüsü. 
İSPIR, N. Bilge \& SUHER, H. Kemal (2009). Sms Reklamlarına Yönelik Tüketici Tutumları. Selçuk Illetişim, 5, 4, 5-17.

KAĞITÇıBAŞ̧I, Çiğdem. (2008). Sosyal Psikolojiye Giriş (11. Basım). İstanbul: Evrim Yayıncilik.

KILIÇ, Sabiha \& ÜNVER, Ahmet Emin (2017). Mobil Reklamcıllkta Müşteri Memnuniyeti: Sosyal Medya Kullanıcıları Üzerinde Bir Araştırma. Girişimcilik Inovasyon ve Pazarlama Araştırmaları Dergisi, 1(1), 39-66.

LEPPANIEMI, Matti \& KARJALUOTO, Heikki (2008). Mobile Marketing: From Marketing Strategy to Mobile Marketing Campaign Implementation. International Journal of Mobile Marketing, 3(1), 50-61

MACKENZIE, SCOTT B. \& LUTZ, Richard J. (1989). An Empirical Examination of the Structural Antecedents of Attitude Toward the Ad in an Advertising Pretesting Context. Journal of Marketing, 53(2), 48-65.

PAVLOU, Paul, A. \& STEWART, David, W. (2000). Measuring the Effects and Effectiveness of İnteractive Adverting: A Research Agenda. Journal of Interactive Advertising, 1(1), 62-78.

SIAU, Keng \& SHEN, Zixing (2003). Building Customer Trust in Mobile Commerce. Communications of the ACM, 46(4), $91-94$.

SíLAH, Mehmet (2005). Sosyal Psikoloji (2.Baskı). Ankara: Seçkin Yayınc1lık.

TABACHNICK, Barbara G. \& FIDELL, Linda S. (2007). Using Multivariate Statistics, (5th Ed.) Pearson, Newyork.

TSANG, Melodi, M., HO, Shu-Chun \& LIANG, Ting-Peng (2004). Consumer Attitudes Toward Mobile Advertising: An Empirical Study. International Journal of Electronic Commerce, 8(3), 65-78.

USTA, Resul (2009). Üniversite Öğrencilerinin Mobil Reklamcıllı̆a Karşı Tutumları. Doğuş Üniversitesi Dergisi, 10(2), 294-309.

XU, David Jingjun (2006/2007). The Influence Of Personalization in Affecting Consumer Attitudes Toward Mobil Advertising in China. The Journal of Computer Information Systems, 47(2), 9-19.

ZİA, ul Hag. (2009). E-mail advertising: A study of consumer attitude toward e-mail advertising among Indian users. Journal of Retail \& Leisure Property, 8(3), 207-223.

http://www.pau.edu.tr/oidb/tr/sayfa/ogrenci-sayilari, Erişim tarihi (08.11.2017). 